\title{
Effectiveness of coir dust and rubber latex based slow release fertilizer on the growth of immature rubber (Hevea) and soil nutrient availability
}

\author{
R P Hettiarachchi*, J A S Chandrasiri*, K E De Silva*, V Edirimanna*, \\ A Thewarapperuma*, T Gunathilake*, G C Malawaraarachchi*, \\ K M M E K Kulathunge*, M W H Gayan* and N S Siriwardana*
}

* Rubber Research Institute, Dartonfield, Agalawatta, Sri Lanka

\begin{abstract}
Slow release type of fertilizers (SRF)enhance nutrient retention in soil, increase fertilizer use efficiency and mitigate environmental problems. As such techniques, this study examined the influence of encapsulated coir bricks $(E C B)$ on the growth of immature Hevea plants at field conditions. Single application of two types of ECB;ECB type 1 and ECB type 2 which were produced by using different quantities of inorganic fertilizers with filling mediums were evaluated against the conventional type of four split applications. Plant diameter was measured at 6 months after planting and plant girth was measured at 12 and 18 months after planting. Leaf nutrients, soil nutrients and soil $\mathrm{pH}$ were measured at 18 months after planting. Application of two types of $E C B$ and conventional type of fertilizer gave almost identical growth performances; with reference to plant diameter and girth. Moreover, ECB type 2 recorded the highest plant diameter at 6 months after planting $(1.65 \mathrm{~cm})$ and plant girth at 12 months after planting $(10.545 \mathrm{~cm})$ and 18 months after planting $(14.81 \mathrm{~cm})$ even though not shown significant differences among treatments. Leaf macro nutrients; $N, P, K, M g$ and soil total $N$, available $P$, exchangeable $C a$ and $p H$ values were also comparable. Significantly higher exchangeable soil $K$ values were observed with ECB applications over the conventional type fertilizer application. Moreover, the highest available soil $P$ (26.4 ppm), exchangeable $K$ (168 ppm), exchangeable Ca (258 ppm) and Mg (31.72 ppm) could be observed with SRF applications. On the above ground, there is a possibility of using single application of both types of ECB as a substitute for four split applications of conventional fertilizers recommended for immature rubber plants.
\end{abstract}

Key words: Hevea, leaf nutrients, plant growth, soil nutrients

\section{Introduction}

Application of $\mathrm{N}, \mathrm{P}, \mathrm{K}$ and $\mathrm{Mg}$ in a correct proportion is essential to obtain optimum growth rates especially during immature phase of rubber (Sivanadyan $e t$ al., 1975 and Yogaratnam et al., 1984) and to attain high yields and sustainable productivity throughout the mature period of rubber plants (Samarappuli and Yogaratnam, 1997 and Yogaratnam and Weerasuriya, 1984). Therefore different fertilizer mixtures were formulated to 
R P Hettiarachchiet al.

suit different soil groups mostly utilized for rubber plantations (Silva, 1971; Yogaratnam et al., 1984). However, the application of about $40-70 \%$ of $\mathrm{N}$ and $80-90 \%$ of $\mathrm{P}$ as conventional fertilizers are wasted in the environment or chemically bound in the soil hence are unavailable to plants (Giroto et al., 2017). Loss of nutrients through removal of old rubber trees at replanting, erosion, leaching, volatilization and fixation of some nutrients are the processes which reduce nutrient availability in most of the rubber growing soils in Sri Lanka. Therefore, nutrient management of rubber growing soils needs to be done in a systemic manner (Samarappuli,1996).

The above mentioned losses cause uneconomical return on capital investment and adverse environmental impact (Majeed et al., 2015), which are challenges for the sustainability of modern agriculture. To avoid this negative environmental consequences, fertilizer use efficiency must be increased (Shaviv and Mikkelsen, 1993; Trenkel, 2010). Therefore, development of suitable alternative to optimize the use of fertilizers is essential approach to enhance nutrient retention in soil, increase fertilizer use efficiency and mitigate environmental problems ( $\mathrm{Li}$ et al., 2015). There are a variety of strategies available to increase fertilizer use efficiency. It includes methods such as split application, precision fertilization, fertigation and the use of environmental friendly fertilizers (Shaviv, 2005; Li et al., 2016).

Slow release fertilizers (SRF) are purposely designed to release their nutrient contents gradually in order to match with the nutrient requirement of the plants and are available for plants over an extended period of time (Sempeho et al., 2014). SRF can be generally classified into several groups such as low solubility organic fertilizer, low solubility inorganic fertilizer, coated fertilizer and matrix based fertilizer etc. However, research on the preparation of slow release fertilizers have mainly focused on coated fertilizers. These fertilizers can be physically prepared by coating granules of conventional fertilizers with various materials that reduce their dissolution rates (Shavit et al., 2002). Various materials have been used as coating to retard nutrient releases and to increase fertilizer use efficiency. To develop environmental friendly fertilizers, effort has been put to utilize eco-friendly coating materials which are naturally available. These natural materials display multiple advantages over synthetic polymers due to their ecofriendly source, a low cost, and easily available and biodegradability (Wezel $e t$ al., 2014; Schneider et al., 2016). Chitosan, extracted from crustaceous water animals, sodium alginate extracted from brown seaweed, starch and its derivatives, cellulose and their derivatives, agricultural residues, biochar, polydopamine are the materials commonly used throughout the world for making environmental friendly coated slow release type fertilizers (Chen et al., 2018).

A huge amount of coir dust is produced after extraction of fiber from coconut husk and is available in coconut growing areas in Sri Lanka. Coconut fiber products are now exported and there is a 
market price for coir dust currently. However, it is a spongy material, can absorb ample quantity of water compared to its weight and showed high in nutrient retention capacity and highly resistant to environmental biodegradation (Abad et al., 2005). Therefore, it is beneficial to utilize coir dust to produce slow release type high value product. The material corncob is also a byproduct of corn production. Recently, it has been utilized for the production of slow release type fertilizers (Wen et al., 2017). However, a new technology for producing Encapsulated Coir Bricks (ECB) has been developed using rubber latex and coir dust as the coating material. This has the advantages of simplicity, economy and not involving any organic or inorganic solvent, thus making it environmental friendly.

The objective of this study is to evaluate the effectiveness of coir and rubber latex based slow release fertilizer on growth of immature rubber plants and soil nutrient availability under field conditions.

\section{Materials and Methods}

An experiment was laid down at Rigama estate, Horana to study the effectiveness of ECB on soil fertility, and their influence on mineral composition of rubber leaves and growth of Hevea genotype Rubber Research Institute of Sri Lanka (RRISL) 203. Young budding polybag plants were planted in the field with the onset of rains. Treatments were arranged in randomized complete block design with five replicates and 25 plants per each replicate. Two months after planting, treatments were imposed according to the pattern shown in Table 1. Nitrogen $(\mathrm{N})$, phosphorus $(\mathrm{P})$, potassium $(\mathrm{K})$ and magnesium $(\mathrm{Mg})$ containing fertilizer mixture $\mathrm{R} / \mathrm{U}$ 12:14:14 and kieserite were applied as two different ECB and $100 \%$ of the RRISL recommended inorganic fertilizers for immature rubber was applied as control treatment. Two types of ECB were applied as once per year and fertilizers for control treatment was applied at three months intervals with four split applications per year according to the recommendation of the RRISL throughout the experimental period from 2017 May to December 2018. During the first year after planting, the fertilizers and ECB were applied in a circle, free of weeds, $25-30 \mathrm{~cm}$ from the base of the plant. The radius of the circle increases with age, up to about $100-120 \mathrm{~cm}$ at the end of fifth year. This experiment was established at estate sector and maintained under normal weather condition. 
R P Hettiarachchiet al.

Table 1. Treatment combinations of the experiment

\begin{tabular}{ll}
\hline Treatment & Description \\
\hline T1 & 275g of NPK mixture R/U 12:14:14 and $75 \mathrm{~g}$ of Kieserite in 4 applications \\
T2 & $\begin{array}{l}\text { Application of four coir bricks, } 50 \mathrm{~g} \text { of NPK mixture R/U 12:14:14 and } 10 \\
\mathrm{~g} \text { of Kieserite per brick, Type } 1(60 \mathrm{~g} \text { of } \mathrm{R} / \mathrm{U} 10: 12: 12: 4)\end{array}$ \\
$\mathrm{T} 3$ & $\begin{array}{l}\text { Application of four coir bricks, } 60 \mathrm{~g} \text { of NPK mixture R/U 12:14:14 and } 15 \\
\mathrm{~g} \text { of Kieserite per brick, Type } 2(75 \mathrm{~g} \text { of R/U 10:12:12:5) }\end{array}$ \\
\hline
\end{tabular}

\section{Growth assessments}

Stem diameter was taken at $15 \mathrm{~cm}$ above the ground level (Samarappuli, 1992) as a pretreatment measurement and at 6 months after planting and thereafter girth measurements were taken at $120 \mathrm{~cm}$ from the ground level (Tillekeratne and Nugawela, 2001) at 12 and 18 months after planting.

\section{Plant analysis}

Two mature leaves were collected from the middle whorl of the plant and composited the leaves of the randomly selected four plants to form one representative sample per each replicate. Leaf samples were analyzed for assessment of mineral nutrient contents (RRIM 1971a).

\section{Soil analysis}

Soil samples were taken from each replicate from three points across the replicate at the depth of $0-15 \mathrm{~cm}$ using soil auger. Samples within the replicate were bulked separately and then subsamples of approximately $1 \mathrm{~kg}$ of soil were taken and allowed to air dry. Dried soil samples were sieved through $2 \mathrm{~mm}$ sieve and used for the analysis of $\mathrm{pH}$, available $\mathrm{P}$, exchangeable $\mathrm{K}, \mathrm{Ca}$ and $\mathrm{Mg}$.
The soil sieved through $0.5 \mathrm{~mm}$ sieve was used for the determination of total $\mathrm{N}$.

\section{a) Soil $\mathrm{pH}$}

Soil $\mathrm{pH}$ was measured using a Beckman $\mathrm{pH}$ meter in water suspension at 1 soil: 2.5water (Rowell, 1994).

b) Determination of acid extractable phosphorus

The extraction was done by weighing $2 \mathrm{~g}$ of air dried soil that was passed through a $2 \mathrm{~mm}$ sieve into $50 \mathrm{ml}$ containers and adding $20 \mathrm{ml}$ of extractant $(200 \mathrm{ml}$ of 0.5 $\mathrm{N} \mathrm{HCI}$ and $15 \mathrm{ml}$ of $0.03 \mathrm{~N} \mathrm{NH}_{4} \mathrm{~F}$ diluted up to $1 \mathrm{~L}$ with distilled water, $\mathrm{pH}$ adjusted to 1.8). This was shaken for one minute and kept for the soil to settle. The solution was filtered through Whatman No: 42 filter paper and was measured calorimetrically using SKALAR $\mathrm{San}^{++}$ Auto analyzer by the molybdenum blue method using $0.5 \%$ ascorbic acid for reduction (Bremner and Muloaney, 1982).

c) Determination of soil total $\mathrm{N}$ Ground samples $(0.5 \mathrm{~g})$ passed through a $0.5 \mathrm{~mm}$ sieve were weighed into pyrex tubes. One gram of sodium sulphate and $5 \mathrm{ml}$ of conc. $\mathrm{H}_{2} \mathrm{SO}_{4} / \mathrm{Se}$ mixture were 
added and was mixed well and digested. After digestion and cooling, the contents of each test tube were poured into $100 \mathrm{ml}$ volumetric flask and made upto mark with distilled water and were kept overnight. The content of each flask was then filtered through Whatman No: 42 filter paper and the filtrate were analyzed for ammonium $\left(\mathrm{NH}_{4}^{+}\right)$nitrogen using Auto analyzer (Bremner and Muloaney, 1982).

\section{d) Determination of exchangeable cations}

Five grams of $2 \mathrm{~mm}$ sieved air dry soils were shaken $50 \mathrm{ml}$ of $1 \mathrm{M}$ ammonium acetate $(\mathrm{pH}=4.8)$ for 30 minutes using an orbital shaker and left it for 30 minutes and again shaken for another 30 minute and left it another 30 minutes. The suspension was then filtered using Whatman No. 42 filter papers (RRIM 1971b). The extract was analyzed for cations by using the atomic absorption spectrophotometer (Dionisio et al., 2011).

\section{Statistical analysis}

Statistical analysis of the experimental data was done by analysis of variance followed by a mean separation procedure, Duncan's Multiple Range test (DMRT), at a probability level of 0.05 .

\section{Results and Discussion}

The soil has been classified as Boralu series (Silva, 1964). These soils belong to great soil group of red yellow podzolic (RYP) soils and have been classified as
Ultisols according to the FAO-USDA classification system. It is characterized by presence of iron concentrations throughout the soil mass. Pre-treatment soil analysis shown in Table 2.

Table 2. Pre treatment soil properties at the experimental site

\begin{tabular}{ll}
\hline Property & Value \\
\hline $\mathrm{pH}$ & 4.8 \\
Cation Exchange Capacity & 2.5 \\
(CEC) (cmol+/kg) & \\
Organic carbon (\%) & 1.5 \\
Total nitrogen (\%) & 0.076 \\
Available phosphorus (ppm) & $8-10$ \\
Exchangeable K (ppm) & 125 \\
Exchangeable Mg (ppm) & 250 \\
\hline
\end{tabular}

The assessment of plant diameter was made of the immature Hevea plants as a pre treatment measurement and six months after commencement of the treatments did not show any significant differences between different forms of fertilizer application treatments (Table $3)$. Further, the assessment of plant girth was made at the end of 12 months (one year) and eighteen months (11/2 years) after commencement of the treatments did not show any significant differences between different forms of fertilizer application treatments (Table 3). It seems that conventional split fertilizer application treatment and single application of ECB treatments create similar nutrient availabilities in the environment, hence comparable growth parameters could be observed with different treatments. 
R P Hettiarachchiet al.

Table 3. Effect of different fertilizer applications on growth of immature rubber plants

\begin{tabular}{lllll}
\hline \multirow{2}{*}{ Treatments } & \multicolumn{2}{c}{ Plant diameter $(\mathbf{c m})$} & \multicolumn{2}{c}{ Plant girth $(\mathbf{c m})$} \\
\cline { 2 - 5 } & Pre treatment & $\begin{array}{l}\text { After } \\
\text { 6 months }\end{array}$ & $\begin{array}{l}\text { After } \\
\mathbf{1 2} \text { months }\end{array}$ & $\begin{array}{l}\text { After } \\
\mathbf{1 8} \text { months }\end{array}$ \\
\hline T1 & $0.97^{\mathrm{a}}$ & $1.6^{\mathrm{a}}$ & $10.39^{\mathrm{a}}$ & $14.54^{\mathrm{a}}$ \\
$\mathrm{T} 2$ & $0.99^{\mathrm{a}}$ & $1.6^{\mathrm{a}}$ & $10.145^{\mathrm{a}}$ & $14.74^{\mathrm{a}}$ \\
$\mathrm{T} 3$ & $1.005^{\mathrm{a}}$ & $1.65^{\mathrm{a}}$ & $10.545^{\mathrm{a}}$ & $14.81^{\mathrm{a}}$ \\
CV & 4.66 & 5.14 & 4.35 & 2.16 \\
\hline
\end{tabular}

Values in the same column followed by the same letter are not significantly different at $\mathrm{p}=0.05$.

Nutrient contents of leaves were measured at the end of eighteen months after commencement of the experiment is given in Table 4. No significant differences could be observed between different fertilizer application treatments for leaf nutrients $\mathrm{N}, \mathrm{P}, \mathrm{K}$ and $\mathrm{Mg}$. Several studies so far reported that soil nutrient levels of $\mathrm{N}, \mathrm{P}, \mathrm{K}$ and $\mathrm{Mg}$ in Hevea ecosystem are reflected by the leaf nutrient levels (Yew and Pushparajah, 1984; Guha and Yew, 1966; Tan, 1972). Accordingly, application of different fertilizers maintains nutrient availabilities in soils and their effect could be observed as assessment of leaf nutrient contents.

Soil fertility parameters were measured at the end of eighteen months after commencement of the experiment are given in Table 5. The parameters, soil
$\mathrm{pH}$, total $\mathrm{N}$, available $\mathrm{P}$ and exchangeable $\mathrm{Ca}$ showed no significant differences between different fertilizer application treatments. However, exchangeable $\mathrm{K}$ content was significantly higher in ECB treatments (T2 and T3) compared to conventional fertilizer application treatment (T1) and no differences could be observed in ECB application treatments (T2 \& T3) (Table $5)$. There is no significant difference between conventional fertilizer application treatment (T1) and ECB treatments (T2 \& T3) for exchangeable $\mathrm{Mg}$ content. However, significant differences could be observed between ECB treatments and ECB type 2 treatment (T3) gave significantly higher exchangeable $\mathrm{Mg}$ content compared to ECB type 1 treatment (T2) (Table 5).

Table 4. Effect of different fertilizer applications on leaf nutrient contents of immature rubber plants

\begin{tabular}{lllll}
\hline \multirow{2}{*}{ Treatments } & \multicolumn{4}{c}{ Leaf nutrient contents (\%) } \\
\cline { 2 - 5 } & $\mathbf{N}$ & $\mathbf{P}$ & $\mathbf{K}$ & $\mathbf{M g}$ \\
\hline $\mathrm{T} 1$ & $2.92^{\mathrm{a}}$ & $0.112^{\mathrm{a}}$ & $0.752^{\mathrm{a}}$ & $0.21^{\mathrm{a}}$ \\
$\mathrm{T} 2$ & $2.91^{\mathrm{a}}$ & $0.117^{\mathrm{a}}$ & $0.785^{\mathrm{a}}$ & $0.25^{\mathrm{a}}$ \\
$\mathrm{T} 3$ & $2.77^{\mathrm{a}}$ & $0.122^{\mathrm{a}}$ & $0.750^{\mathrm{a}}$ & $0.23^{\mathrm{a}}$ \\
$\mathrm{CV}$ & 7.19 & 16.78 & 5.72 & 26.99 \\
\hline
\end{tabular}

Values in the same column followed by the same letter are not significantly different at $\mathrm{p}=0.05$. 
Slow release fertilizer for immature rubber

Table 5. Effect of different fertilizer applications on soil $p H$, total $N$, available $P$, exchangeable $\mathrm{K}, \mathrm{Ca}$ and $\mathrm{Mg}$ of the top $0-5 \mathrm{~cm}$ soil layer at the end of 18 months after planting

\begin{tabular}{lllllll}
\hline Treatments & $\mathbf{p H}$ & $\begin{array}{l}\text { Total } \\
\mathbf{N}\end{array}$ & $\begin{array}{l}\text { Available } \\
\mathbf{P}\end{array}$ & $\begin{array}{l}\text { Exchangeable } \\
\mathbf{K}\end{array}$ & $\begin{array}{l}\text { Exchangeable } \\
\text { Ca }\end{array}$ & $\begin{array}{l}\text { Exchangeable } \\
\mathbf{M g}\end{array}$ \\
\hline $\mathrm{T} 1$ & $5.11^{\mathrm{a}}$ & $0.162^{\mathrm{a}}$ & $25.8^{\mathrm{a}}$ & $158^{\mathrm{b}}$ & $238^{\mathrm{a}}$ & $29.17^{\mathrm{ab}}$ \\
$\mathrm{T} 2$ & $5.18^{\mathrm{a}}$ & $0.152^{\mathrm{a}}$ & $22.8^{\mathrm{a}}$ & $175^{\mathrm{a}}$ & $258^{\mathrm{a}}$ & $26.82^{\mathrm{b}}$ \\
$\mathrm{T} 3$ & $5.12^{\mathrm{a}}$ & $0.157^{\mathrm{a}}$ & $26.4^{\mathrm{a}}$ & $168^{\mathrm{a}}$ & $242^{\mathrm{a}}$ & $31.72^{\mathrm{a}}$ \\
$\mathrm{CV}$ & 3.26 & 12.69 & 15.03 & 3.17 & 11.72 & 9.14 \\
\hline
\end{tabular}

Values in the same column followed by the same letter are not significantly different at $\mathrm{p}=0.05$.

Soti et al., 2015 observed that there were no differences in growth parameters among the different slow release fertilizers. Single application of polymer-coated urea fertilizer with varying degrees of $\mathrm{N}$ release (different formulations were made by varying the coating contents) could increase the $\mathrm{N}$ use efficiency, compared to normal urea split applications in the three major grain crops, rice (Yang et al., 2012b; 2013), wheat (Yang et al., 2011), and corn (Ning et al., 2012). Improved $\mathrm{N}$ use efficiencies were resulted from the use of polymer-coated urea providing 3.23$26 \%$ yield increases compared to normal split applications (Wang et al., 2016). Moreover, Yang et al., 2012b observed no significant increase in rice yield accompanying a $25 \%$ enhancement in $\mathrm{N}$ use efficiency with coated fertilizer when compared to normal application of $\mathrm{N}$ rate of $300 \mathrm{kgNha}^{-1}$ in the first year. However, yield greatly increased by $18 \%$ with coated fertilizer in the second year with $22.9 \%$ in $\mathrm{N}$ use efficiency. According to Dong et al., 2016, some physiological characteristics such as chlorophyll content, photosynthetic rate, transpiration rate and chlorophyll fluorescence parameters have increased significantly providing $24-35 \%$ more grain yield and $57-74 \%$ more total yield with coated fertilizer treated maize plants when compared to application of conventional compound fertilizer. Similar to these results, present study revealed that there is a possibility of using ECB as a substitute for split application of conventional fertilizers.

\section{Conclusions}

In this study it was revealed that the growth parameters of plant diameter and girth of immature rubber plant, leaf nutrients; $\mathrm{N}, \mathrm{P}, \mathrm{K} \& \mathrm{Mg}$ and some soil nutrients; $\mathrm{N}, \mathrm{P} \mathrm{Ca}$ and $\mathrm{Mg}$ were comparable between ECB treatments and conventional split fertilizer application treatment. Enhancement of exchangeable $\mathrm{K}$ could be observed with ECB treatments compared to conventional fertilizer application. Further, ECB application reduces the labour cost of Rs.36,225/= per hectare is due to net saving for labour compared to the conventional type of fertilizer application. Hence, it can be concluded that there is a possibility of using single application of ECB as a substitute for four split application of conventional fertilizers recommended for immature 
R P Hettiarachchiet al.

rubber plants with net saving of Rs.36,225/= per hectare.

\section{Future studies}

The efficiency of the produced ECB was similar to the conventional split fertilizer application was proven for the rubber plants growing in Boralu series soils and to be evaluated in other rubber growing environments in future studies.

New technologies should be developed or existing technologies should be improved for mass production of ECB. ECB has been developed using rubber latex and coir dust as the coating materials. Other environmental friendly low cost materials should also be explored for the preparation of slow release product.

\section{References}

Abad, M, Fornes, F Carrión, Noguera, CV, Noguera, P, Maquieira, Á and Puchades, R (2005). Physical properties of various coconut coir dusts compared to peat.HortScience 40(7), 2138-2144.

Bremner, J M and Mulvaney, C S (1982). Nitrogen-Total. p. 595-624. In: A L Page et al. (ed.) Methods of Soil Analysis. Part 2. Chemical and Microbiological Properties. American Society of Agronomy, Soil Science Society of America, Madison, Wisconsin.

Chen, J, Lü, S, Zhang, Z, Zhao, X, Li, X, Ning, $P$ and Liu, M (2018). Environmentally Friendly Fertilizers: A review of materials used and their effects on the environment. Science of the total environment. 613-614, 829-839.

Dionisio, A G G, de Jesus, A M D R S, Amais, G L, Donati, Miranda, K A, Guerra, M B B, Nobrega, J A and Pereirafilho, E R (2011). Old and new flavours of Flame (Furnace) Atomic Absorption
Spectrophotometer.

International Journal of Spectroscopy. 1-30.

Dong, Y J, He, M R, Wang, Z L, Chen,W F, Hou, J, Qiu, X K and Zhang, J W (2016). Effect of new coated release fertilizer on the growth of maize. Journal of Soil Science and Plant Nutrition 16(3): 637 649.

Giroto, A S, Guimaraes, G G F, Foschini, M and Ribeiro, C (2017). Role of slowrelease nanocomposite fertilizers on nitrogen and phosphate availability in soil. Scientific Reports 7, 46032-46039.

Guha, M M and Yew, K H (1966). Soil and leaf nutrient status in relation to soil type. Plrs Bull. Rubber Research Institute of Malaya 87, 170.

Li, X, Li, Q, Xu, Y, Yue, Q, Gao, B and Su, Y (2015). Novel wheat straw cellulosebased semi-ITNs superabsorbent with integration of water- retaining and controlled released fertilizers.J. Taiwain Inst. Chem. Eng. 55, 170-179.

Li, X, Li, Q, Xu, Y, Yue, Q, Gao, B and Su, $Y$ (2016). Characterization, swelling and slow- release properties of a new controlled release fertilizer based on wheat straw cellulose hydrogen. $J$. Taiwain Inst. Chem. Eng. 60, 564-572.

Majeed, Z, Ramli, N K, Mansor, N and Man, $\mathrm{Z}$ (2015). A comprehensive review on biodegradable polymers and their blend used in controlled release fertilizer processes. Rev. Chem. Eng. 31, 69-95.

Ning, T Y, Shao, G Q, Li, Z J, Han, H F, Hu, H G, Wang, Y, Tian, S Z and Chi, S Y (2012). Effects of urea types and irrigational crop uptake soil residual, and loss of nitrogen in maize field on the North China Plain. Plant Soil Environ.58, 1-8.

Rowell, D L (1984). Soil Science: Methods and Applications. Longman Scientific and Technical, Longman Group UK Ltd., Harlow, Essex, UK. 
Rubber Research Institute of Malaysia (1971a). Manual of Laboratory Methods of Leaf Analysis. Malaysia.

Rubber Research Institute of Malaysia (1971b). Manual of Laboratory Methods of Soil Analysis, Malaysia.

Samarappuli, L (1992a). Effects of some soil management practices and moisture regimes on the performance of Hevea. PhD Thesis, University of Peradentya, Sri Lanka.

Samarappuli, L (1996). The contribution of rubber plantation towards a better environment. Bulletin of the Rubber Research Institute of Sri Lanka 33, 45-54.

Samarappuli, L and Yogaratnam, N (1997). Soil management practices in rubber plantation and their effect on the environment. Bulletin of the Rubber Research Institute of Sri Lanka 35, 7-18.

Schneider, Teixeira, Deladino, A L and Zaritzky, N (2016). Yerba mate (Ilex paraguarienis) waste and alginate as a matrix for the encapsulation of $\mathrm{N}$ fertilizer. ACS Sustain. Chem. Eng. 4, 2449-2458.

Sempeho, S I, Kim, H T, Mubofu, E and Hilonga, A (2014). Meticulous overview on the controlled release fertilizers. Advances in Chemistry. Available at http://dx.doi.org/10.1155/2014/363071.

Shavit, V, Reiss, M and Shaviv, A (2002). Wetting mechanisms of gel based controlled release fertilizers. J. Control. Release 88, 71-83.

Shaviv, A (2005). Environmental friendly nitrogen fertilization. Sci. China Ser. C 48, 937-947.

Shaviv, A and Mikkelsen, R (1993). Controlled release fertilizers to increase efficiency of nutrient use and minimize environmental degradation - a review. Fertile. Res 35, 1-12.

Silva, C G (1971). An evaluation of the nutritional status of rubber soils of
Ceylon. Quarterly Journal of the Rubber Research Institute of Ceylon 48, 147-159.

Silva, C G (1964). Provisional classification of rubber soils of Ceylon and their relationship to Malayan soils. Jl. Rubber Research Inst. Malaya 24, 217-224.

Sivanadyan, K Haridas, G and Pushaparajah, E (1975). Reduced immaturity period of Hevea brasiliensis. Proc. Int. Rubb. Conf. Kuala Lumpur 3, 147-157.

Soti, P, Fleurissaint, A, Reed, S and Jayachandran, K (2015). Effect of controlled release fertilizers on nutrient leaching palm growth and production cost. Agriculture 5, 1135-1145.

Tan, K H (1972). Relationship between some laboratory soil nitrogen availability indices and plant indices of two crops. (Hevea brasiliensis and Oryza sativa) Proc. $2^{\text {nd } A S E A N}$ Soil Conf. Bogor, Indonesia. 217.

Tillekeratne, L M K and Nugawela, A (2001). Hand Book of Rubber: Vol. 1, Agronomy, $2^{\text {nd }}$ ed. Rubber Research Institute of Sri Lanka.

Trenkel, M E (2010). Slow- and Control Release and Stabilized Fertilizer; An Option for Enhancing Nutrient Use Efficiency in Agriculture. Scientific Research. International Fertilizer Industry Association (IFA) Paris, France.

Wang, S, Zhao, X, Xing, Y, Yang, M, Zhang and Chen, $H$ (2016). Improving grain yield and reducing $\mathrm{N}$ loss using polymer - coated urea in Southeast China. Agron. Sustain. Dev. 35, 1103-1115.

Wen, P, Wu, Z Han, Y, Cravotto, G, Wang, J and Ye, BC (2017). Microwave assisted synthesis of a novel biochar- based slowrelease nitrogen fertilizer with enhanced water retention capacity. ACS Sustain. Chem. Eng.5, 7374-7382.

Wezel, A, Casagrande, Celette, L F, Vian, J F, Ferrer, A and Peigne, J (2014). Agroecological practices for sustainable 
R P Hettiarachchiet al.

agriculture. A review. Agron. Sustain. Dev. 34, 1-20.

Yang, Y C, Zhang, M, Zheng, L, Cheng, D D, Liu, M and Geng, Y Q (2011). Controlled release urea improved nitrogen use efficiency, yield and quality of wheat. Agron J. 103, 479-485.

Yang Y C, Zhang, M, Zheng, L, Cheng, D D, Liu, M and Geng, Y Q (2013). Controlled release urea for rice production and its environmental implications. J. Plant Nutri. 36, 781-794.

Yang Y C, Zhang, M, Li, Y C, Fan, X H and Geng, Y Q (2012). Controlled release urea improved nitrogen use efficiency, activities of leaf enzymes and rice yield. Soil Sci. Soc. Am J.76, 2307-2317.

Yew, F K and Pushparaj, E (1984). Plant tissue as indicated of soil nutrient availability for Hevea, glasshouse evaluation. Journal Rubber Research Institute of Malaysia 32(3), 171-181.

Yogaratnam, N, Silva, F P W and Weerasuriya, S M (1984). Recent developments in the nutrients of Heavea in Sri Lanka. Proceedings of the International Rubber Conference, Rubber Research Institute of Sri Lanka, Dartonfield, Agalawatta, Sri Lanka. p.207-247.

Yogaratnam, $\mathrm{N}$ and Weerasuriya, S M (1984). Fertilizer responses in mature Hevea under Sri Lankan conditions. Journal of Rubber Research Institute of Sri Lanka 62, 19-39.

Address for correspondence: Dr (Mrs) R P Hettiarachchi, Head, Soils \& Plant Nutrition Dept., Rubber Research Institute of Sri Lanka, Dartonfield, Agalawatta, Sri Lanka. e-mail: rrirasika@gmail.com 